\title{
Panencephalopathic type of Creutzfeldt-Jakob disease associated with cadaveric dura mater graft
}

\author{
Masahito Yamada, Yoshinori Itoh, Naomi Suematsu, Masaaki Matsushita, Eiichi Otomo
}

\begin{abstract}
A 52 year old man with Creutzfeldt-Jakob disease who received a cadaveric dura mater graft 99 months before the onset is reported. The prion protein gene was homozygous for methionine at the polymorphic codon 129. Neuropathological examination disclosed a panencephalopathic type of Creutzfeldt-Jakob disease which was characterised by severe involvement of the cerebral white matter and cerebellum, as well as of the cerebral cortical and deep grey matter. Thus the panencephalopathic type of CreutzfeldtJakob disease may occur in association with cadaveric dura mater grafts.
\end{abstract}

(F Neurol Neurosurg Psychiatry 1997;63:524-527)

Keywords: Creutzfeldt-Jakob disease; cadaveric dura matter graft; prion protein

Department of

Neurology, Tokyo

Medical and Dental

University, Yushima,

Bunkyo-ku, Tokyo 113,

Japan

M Yamada

Departments of

Internal Medicine and

Pathology, Yokufukai

Geriatric Hospital

Takaido-nishi,

Suginami-ku, Tokyo

168, Japan

Y Itoh

N Suematsu

E Otomo

Department of Psychiatry, University of Tokyo, Hongo, Bunkyo-ku, Tokyo 113, Japan

M Matsushita

Correspondence to: Dr M Yamada, Department of Neurology, Tokyo Medical and Dental University,

1-5-45, Yushima, Bunkyo-ku, Tokyo 113, Japan.

Received 28 August 1996 and in revised form 12 February 1997

Accepted 7 April 1997
Creutzfeldt-Jakob disease may develop associated with cadaveric dura mater grafts: since the first report by Thadani et al, ${ }^{1}$ there have been published reports of 19 cases of dural graft associated Creutzfeldt-Jakob disease (reviewed by Brown ${ }^{2}$ ). Clinically, most patients presented with ataxia, alone or in combination with visual symptoms or mental deterioration. ${ }^{2}$ However, neuropathological features of CreutzfeldtJakob disease associated with dural grafts is not fully understood. Clinical and neuropathological presentations of Creutzfeldt-Jakob disease would be influenced by several factors including the prion strain of contaminated dura mater grafts and polymorphism of the prion protein (PrP) gene of the host. Analyses of the neuropathological as well as clinical features would lead to better understanding of such factors.

We report another case of Creutzfeldt-Jakob disease after cadaveric dura mater graft, in which the neuropathology was of a panencephalopathic type. ${ }^{3}$ The neuropathological and clinicopathological features of the dural graft associated Creutzfeldt-Jakob disease are analysed together with a review of the literature.

\section{Case report}

The patient was a 52 year old man at the time of death. He underwent removal of a right frontal convexity meningioma on 24 December 1984, at the age of 43. A graft of cadaveric dura mater (Lyodura, B Braun Melsungen AG, Germany), was used, covering part of the right frontal lobe.

He stayed asymptomatic until March 1993 (99 months after surgery) when he complained of appetite loss, dysaesthesia of the throat, and blurred vision. On 5 April, during a game of golf, he suddenly developed ataxic gait and dysarthria. He became confused, and thereafter, mental deterioration rapidly progressed. He became bedridden on 22 April and was admitted to hospital. Neurologically, he showed akinetic mutism, paratonic rigidity of the limbs, exaggerated deep tendon reflexes, myoclonus, and startle reaction to auditory stimuli. Cranial CT was normal except for postoperative state of the right frontal area. His CSF was normal. On EEG, periodic synchronous discharge was found with generalised slowing. The clinical diagnosis was Creutzfeldt-Jakob disease. Cranial MRI in

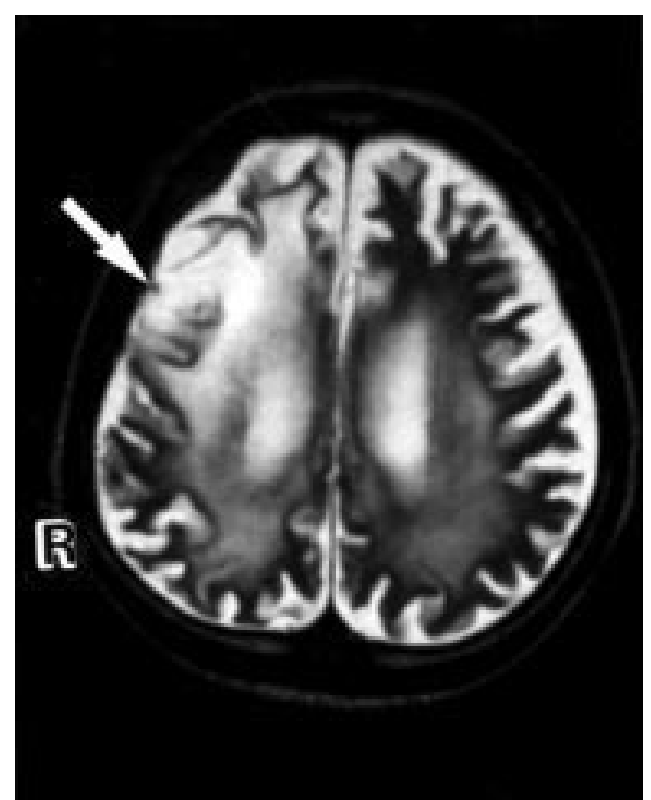

Figure $1 \quad T 2$ weighted MRI nine months after onset of disease. There are bilateral diffuse high intensity lesions of the white matter and cortical atrophy in addition to the postoperative condition of the right frontal lobe (arrow). 
December disclosed diffuse brain atrophy with high intensity lesions of bilateral cerebral white matter in T2 weighted images (fig 1). He died of pneumonia on 21 January 1994 (10 months
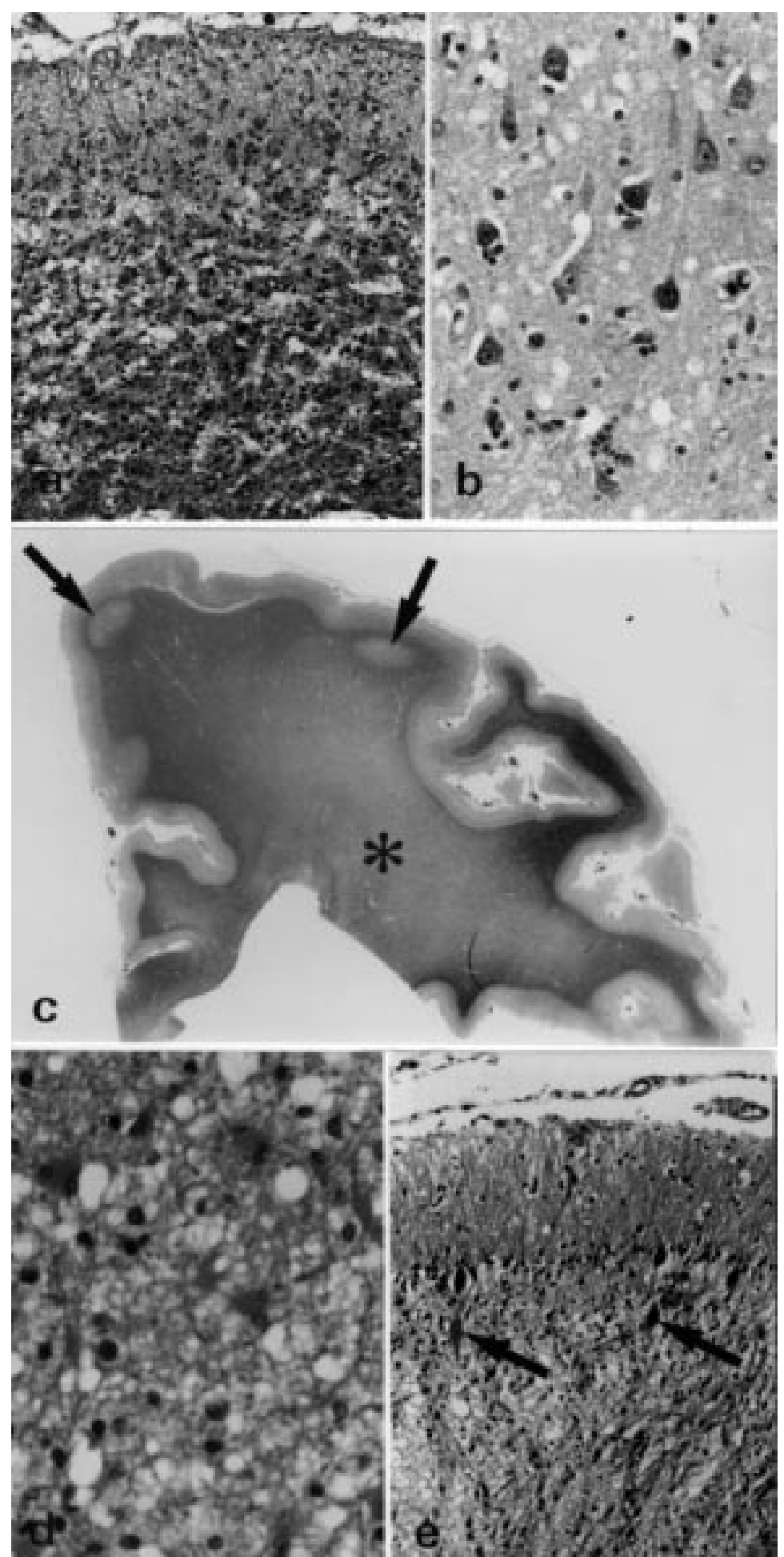

Figure 2 Histological findings. (a) The frontal cortex shows a prominent loss of neuronal cells, many hypertrophic astrocytes, and spongy state of the tissue. (b) In the subiculum, spongiform changes are seen between the pyramidal cells. (c) The cerebral white matter shows diffuse myelin pallor (asterisk) and focal circumscribed lesions (arrows) in the subcortical areas. (d) With higher magnification, the circumscribed white matter lesions have a spongy appearance with proliferation of hypertrophic astrocytes and foamy cells. (e) In the cerebellar cortex, there is pronounced loss of the granule cells with severe fibrillary gliosis. Purkinje cells appear shrunken, but preserved in number; torpedoes (arrows) are often seen in the granule cell layer. (a, Luxol fast blue (LFB)-haematoxylin and eosin $(H E), \times 75 ; b, L F B-H E, \times 256 ; c, L F B-H E \times 1.6 ; d, L F B-H E, \times 300 ; e, L F B-H E, \times 99)$. after the onset). Necropsy limited to the brain was performed 19 hours postmortem.

The brain was $760 \mathrm{~g}$ in weight. The entire brain showed pronounced atrophy. There was an indentation in the right frontal convexity covered by a patch of dura mater graft. On section, the cerebral cortex was very thin, and the ventricles were enlarged. The striatum and thalamus showed brownish atrophy.

Histologically, the cerebral cortex diffusely showed considerable neuronal loss, proliferation of hypertrophic astrocytes, and spongy state or more pronounced destruction of the tissue (fig 2a). The deep grey matter showed the same changes: the striatum and medial nuclei of the thalamus were severely involved. Although the hippocampal formations were preserved compared with the neocortex, definitive spongiform changes could be seen in the subiculum (fig $2 \mathrm{~b}$ ). The cerebral white matter showed diffuse myelin pallor with proliferation of hypertrophic astrocytes and scattered foamy cells (fig 2c). Furthermore, there were several circumscribed lesions in the subcortical white matter (fig 2c). The circumscribed white matter lesions presented with a spongy appearance showing the vacuoles, foamy cells, loss of the myelinated fibres, and hypertrophic astrocytes (fig 2d). In the cerebellum, the cortex showed pronounced atrophy with prominent fibrillary gliosis (fig 2e). A decrease of the granule cells was especially obvious, whereas Purkinje cells were relatively preserved in number. There were frequent formations of torpedoes in the granule cell layer (fig 2e). In the brainstem, a mild spongy state and astrocytic proliferation was found in the periaqueductal grey of the midbrain and pontine nuclei. There was mild degeneration of the pyramidal tracts with astrocytic proliferation.

Immunohistochemistry for $\mathrm{PrP}$ was performed using an affinity purified rabbit polyclonal antibody to a synthetic peptide (amino acid sequence 95-108) of the $\operatorname{PrP}$ in the sections including the cerebral cortex, the white matter lesions, and the cerebellum from the patient, positive control tissues from a patient with Gerstmann-Sträussler-Scheinker's disease associated with a codon 105 mutation, ${ }^{4}$ and negative control tissues from a patient with Alzheimer's disease and from patients with no neurological disease. The cerebral (fig $3 \mathrm{a}$ and c) and cerebellar cortices (fig 3e) showed diffuse granular PrP immunostaining. Absorption of the antibody with the $\operatorname{PrP}$ peptide (amino acid sequence 95-108) before the immunohistochemistry completely blocked the immunostains (fig $3 \mathrm{~b}, \mathrm{~d}$, and $\mathrm{f}$ ), showing the specificities of the immunoreactions. The changes in white matter including the circumscribed spongy lesions disclosed no definitive positive staining for $\operatorname{PrP}$ (fig $3 \mathrm{~g}$ and $\mathrm{h}$ ).

Genomic DNA was extracted from the white blood cells. The open reading frame of the PrP gene was amplified and sequenced as previously described. ${ }^{4}$ There was no mutation in the open reading frame. Codon 129, a polymorphic site of the PrP gene, was homozygous for methionine. 

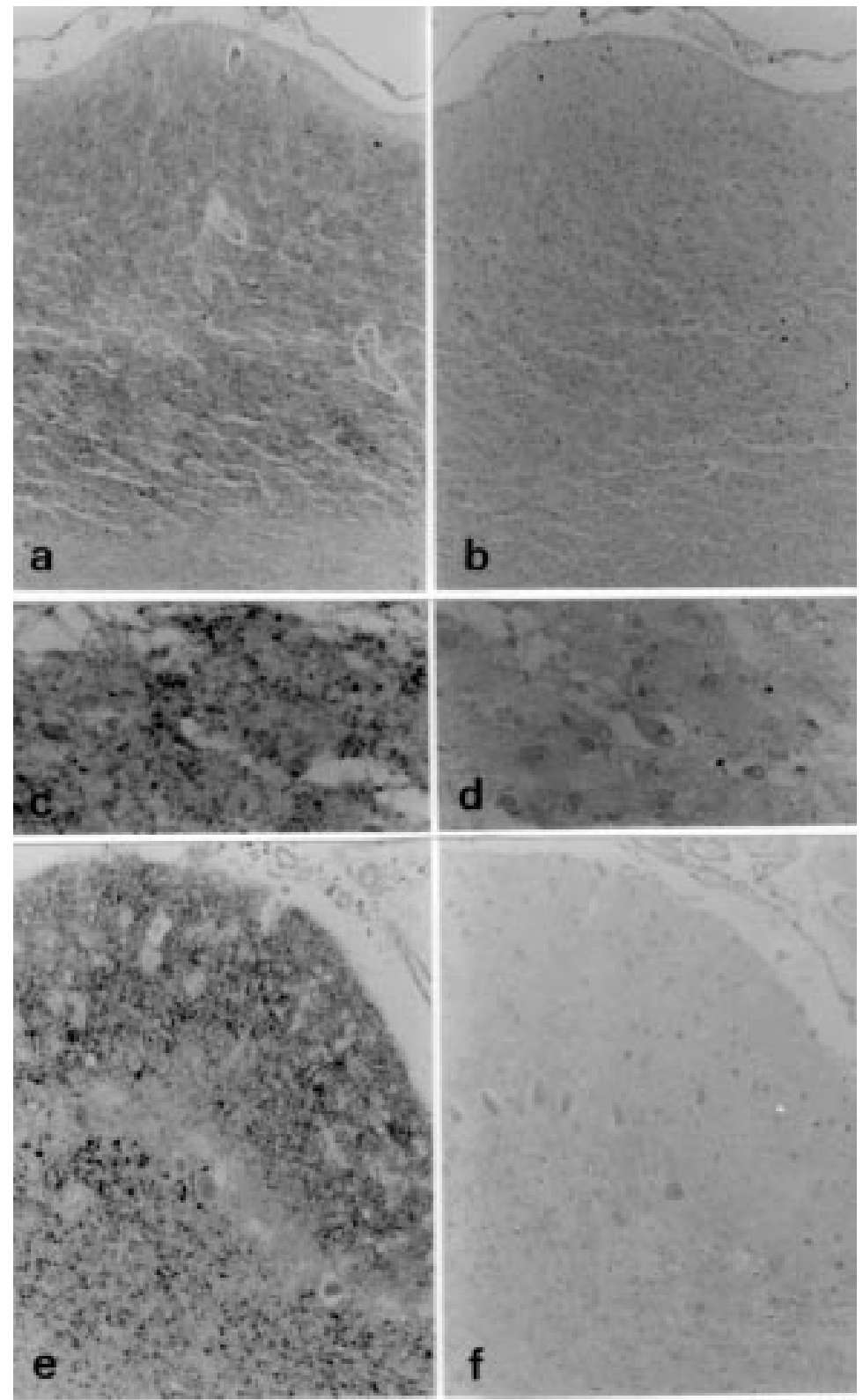

f

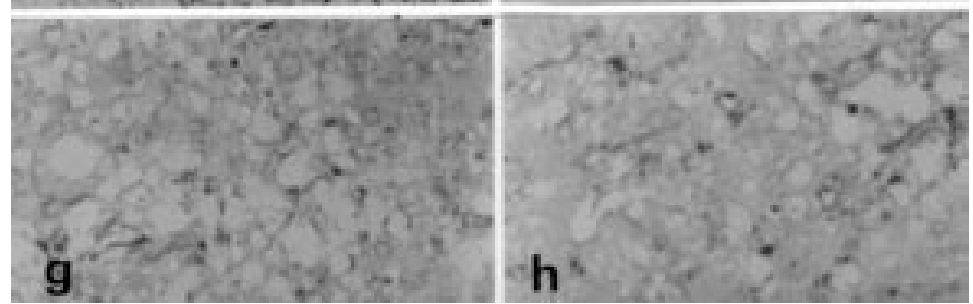

Figure 3 Immunohsitochemical findings with the anti-PrP antibody $(a, c, e, g)$ and preabsorption of the antibody with the PrP peptide as negative controls $(b, d, f, h)$ in the cerebral cortex $(a-d)$, cerebellar cortex $(e, f)$, and cerebral white matter lesion $(g, h)$. The cerebral cortex (a) presents with diffuse PrP immunoreactivities showing granular appearance with higher magnification (c). In the cerebellar cortex (e), the intense granular stains were seen with relative sparing of the Purkinje cell layer. These positive immunoreactivities in the cerebral $(a, c)$ and cerebellar cortices (e) were blocked by preabsorption of the antibody with the $\operatorname{PrP}$ peptide $(b, d, f)$. The circumscribed cerebral white matter lesion, as indicated in fig $2 d$, shows no definitive $\operatorname{PrP}$ accumulation ( $g$ ) compared with the negative control $(h)$. ( $a, b, \times 51 ; c, d, \times 320 ; e, f, \times 128 ; g, h, \times 320)$

\section{Discussion}

The clinical features of our patient were consistent with the findings reported in the Lyodura-grafted cases of Creutzfeldt-Jakob disease including the time of surgical operations, incubation periods, neurological mani- festations, and codon 129 homozygosity of the PrP gene. ${ }^{2}$

Neuropathologically, our patient presented with the panencephalopathic type of Creutzfeldt-Jakob disease. This type, first reported by Mizutani et $a l{ }^{3}$ is characterised by severe and extensive white matter lesions in addition to the typical spongiform changes of the cerebral cortex. ${ }^{3}$ The white matter changes include circumscribed spongy foci, which suggest primary involvement of the white matter. ${ }^{3}$ Severe cerebellocortical involvement of granular cell type is also found in the panencephalopathic type. ${ }^{3}$ In the PrP immunohistochemistry, we could find no definitive PrP accumulation in the white matter lesions, although the cerebral cortex and cerebellum showed the diffuse granular PrP immunostaining typical of Creutzfeldt-Jakob disease. Pathogenesis of the panencephalopathic type of Creutzfeldt-Jakob disease remains to be elucidated.

To delineate neuropathological characteristics of the dural graft associated disease, we reviewed the neuropathological findings for the six necropsied cases, in which distributions of the lesions were reported, ${ }^{5-10}$ and our patient (table).

All the patients showed spongiform change of the cerebral cortex. It should be noted that the cerebellar cortical involvement, affecting granule cells more than Purkinje cells, was found in all the cases of Creutzfeldt-Jakob disease associated with dural grafts. This is compatible with the common clinical presentation of ataxic symptoms in the cases associated with dural grafts, whereas in sporadic cases, about $10 \%$ of the patients had cerebellar ataxia alone when examined initially, or had cerebellar ataxia in association with an organic mental syndrome, and most of the ataxic cases showed neuropathologically severe cerebellar involvement. ${ }^{11}$ Patients with Creutzfeldt-Jakob disease associated with peripheral injections of pituitary hormones derived from cadavers, the most frequent cause of iatrogenic transmission, stereotypically develop progressive cerebellar signs; pathologically, the cerebellar cortex is severely involved with or without Kuru plaques, whereas involvement of the cerebral cortex is milder. ${ }^{212}$ By contrast, both the cerebral and cerebellar cortex are severely involved in cases of Creutzfeldt-Jakob disease associated with dural grafts.

White matter lesions (loss of myelin and axons with proliferation of astrocytes and foamy cells) were reported in cases $5^{9}$ and $6^{10}$ (table); in those cases, however, there was no description of circumscribed focal lesion, as found in our case. Such focal lesions, in addition to diffuse involvement of the white matter, led to the neuropathological diagnosis of the panencephalopathic type of CreutzfeldtJakob disease $e^{3}$ in our case.

Kuru type amyloid plaques were described only in one exceptional case (5), in which cerebellar symptoms showed relatively slow progression, and the diagnosis was "idiopathic cerebellar degeneration". ${ }^{9}$ In addition, very recently, "florid plaques" as found in a new 
Neuropathological findings of necropsied cases of Creutzfeldt-Fakob disease (CFD) after cadaveric dura mater grafts

\begin{tabular}{|c|c|c|c|c|c|c|c|c|c|c|}
\hline \multirow[b]{2}{*}{ Case No and authors } & \multirow[b]{2}{*}{$\begin{array}{l}\text { Age (y) } \\
/ \text { sex }\end{array}$} & \multirow[b]{2}{*}{$\begin{array}{l}\text { Clinical } \\
\text { diagnosis }\end{array}$} & \multirow[b]{2}{*}{$\begin{array}{l}\text { Codon } \\
129^{\star}\end{array}$} & \multirow[b]{2}{*}{$\begin{array}{l}\text { Brain weight } \\
(g)\end{array}$} & \multirow[b]{2}{*}{$\begin{array}{l}\text { Spongiform } \\
\text { change }\end{array}$} & \multirow[b]{2}{*}{$\begin{array}{l}\text { Kuru type } \\
\text { amyloid } \\
\text { plaques }\end{array}$} & \multicolumn{4}{|c|}{ Distribution of the lesions } \\
\hline & & & & & & & $\begin{array}{l}\text { Cerebral } \\
\text { cortex }\end{array}$ & $\begin{array}{l}\text { Deep } \\
\text { grey } \\
\text { matter }\end{array}$ & $\begin{array}{l}\text { White } \\
\text { matter }\end{array}$ & Cerebellum \\
\hline 1 Miyashita $e t a l^{5}$ & $26 / \mathrm{F}$ & CJD & NE & 920 & + & & + & + & & + \\
\hline 2 Willison et $a l^{6}$ & $30 / \mathrm{M}$ & CJD & $\mathrm{NE}$ & & + & & + & + & & + \\
\hline 3 Pocchiari et $a l^{7}$ & $32 / \mathrm{F}$ & CJD & $\mathrm{Val} / \mathrm{Val}$ & 950 & + & & + & & & + \\
\hline 4 Esmonde $e t a l,{ }^{8}$ case 2 & $44 / \mathrm{F}$ & CJD & $\mathrm{NE}$ & & + & - & + & + & & + \\
\hline 5 Lane $e^{a} a l^{9}$ & $28 / \mathrm{F}$ & $\begin{array}{l}\text { Idiopathic } \\
\text { cerebellar } \\
\text { degeneration }\end{array}$ & $\mathrm{NE}$ & 1200 & + & + & + & + & + & + \\
\hline 6 Yamada et al ${ }^{10}$ & $31 / \mathrm{F}$ & CJD & Met/Met & 750 & + & - & + & + & + & + \\
\hline 7 This case & $52 / \mathrm{M}$ & CJD & Met/Met & 760 & + & - & + & + & $+\dagger$ & + \\
\hline
\end{tabular}

^Polymorphism at codon 129 of the prion protein gene. NE=Not examined.

†Circumscribed spongy foci in the white matter as well as diffuse white matter changes.

variant of Creutzfeldt-Jakob disease was reported to be present in a biopsy tissue from a dura mater grafted case of Creutzfeldt-Jakob disease. ${ }^{13}$

In conclusion, we reported the panencephalopathic type of Creutzfeldt-Jakob disease associated with a cadaveric dura mater graft. The neuropathology was characterised by severe involvement of the white matter and cerebellum as well as of the cerebral cortical and deep grey matter. Further study is required to elucidate the clinicopathological range and pathogenesis of Creutzfeldt-Jakob disease associated with dural grafts.

We thank Dr Koba who referred the patient to us. We also thank Mr Isahai, Mr Takeda, Mr Konuma, and Ms Miura for their excellent technical assistance.

1 Thadani V, Penar PL, Partington J, et al. Creutzfeldt-Jakob disease probably acquired from a cadaveric dura mater disease probably acquired from
graft. $\mathcal{F}$ Neurosurg $1988 ; 69: 766-9$.

graft. $\mathcal{F}$ Neurosurg 1988;69:766-9.
2 Brown P. Environmental causes of human spongiform encephalopathy. In: Baker HF, Ridley RM, eds. Prion diseases. Totowa, NJ: Humana Press, 1996:139-54.

3 Mizutani T, Okumura A, Oda M, Shiraki H. Panencephalopathic type of Creutzfeldt-Jakob disease: primary involve- ment of the cerebral white matter. I Neurol Neurosurg Psychiatry 1981;44:103-15.

4 Yamada M, Itoh Y, Fujigasaki $\mathrm{H}$, et al. A missense mutation at codon 105 with codon 129 polymorphism of the prion protein gene in a new variant of Gerstmann-SträusslerScheinker disease. Neurology 1993;43:2723-4.

5 Miyashita K, Inuzuka T, Kondo H, et al. Creutzfeldt-Jakob disease in a patient with a cadaveric dural graft. Neurology 1991;41:940-1.

6 Willison HJ, Gale A, McLaughlin JE. Creutzfeldt-Jakob disease following cadaveric dura mater graft. $f$ Neurol Neurosurg Psychiatry 1991;54:940.

7 Pocchiari M, Masullo C, Salvatore M, Genuardi M, Galgani S. Creutzfeldt-Jakob disease after non-commercial dura mater graft. Lancet 1992;340:614-5

8 Esmonde T, Lueck CJ, Symon L, Duchen LW, Will RG. Creutzfeldt-Jakob disease and lyophilised dura mater grafts: report of two cases. F Neurol Neurosurg Psychiatry 1993;56:999-1000.

9 Lane KL, Brown P, Howell DN, et al. Creutzfeldt-Jakob Disease in a pregnant woman with an implanted dura mater graft. Neurosurgery 1994;34:737-40.

10 Yamada S, Aiba T, Endo Y, et al. Creutzfeldt-Jakob disease transmitted by a cadaveric dura mater graft. Neurosurgery 1994;34:740-4.

11 Gomori A, Partnow MJ, Horoupian DS, Hirano A. The ataxic form of Creutzfeldt-Jakob disease. Arch Neurol 1973; 29:318-23.

12 Bell JE. Neuropathological diagnosis of human prion diseases. In: Baker HF, Ridley RM, eds. Prion diseases. Totowa, NJ: Humana Press 1996:59-83.

13 Kopp N, Streichenberger N, Deslys JP, Laplanche JL, Chazot G. Creutzfeldt-Jakob disease in a 52-year-old woman with florid plaques. Lancet 1996;348:1239-40. 